South Dakota State University

Open PRAIRIE: Open Public Research Access Institutional

Repository and Information Exchange

Agronomy, Horticulture and Plant Science

Department of Agronomy, Horticulture, and

Faculty Publications

Plant Science

3-2021

Nitrogen Fertilization and Glyphosate-Resistant Alfalfa

Termination Method Effects on First-Year Silage Corn

Jason Clark

Matt A. Yost

Thomas C. Griggs

Grant E. Cardon

Corey V. Ransom

See next page for additional authors

Follow this and additional works at: https://openprairie.sdstate.edu/plant_faculty_pubs

Part of the Agronomy and Crop Sciences Commons 


\section{Authors}

Jason Clark, Matt A. Yost, Thomas C. Griggs, Grant E. Cardon, Corey V. Ransom, and J. Earl Creech 
Crop Economics, Production, and Management

\title{
Nitrogen fertilization and glyphosate-resistant alfalfa termination method effects on first-year silage corn
}

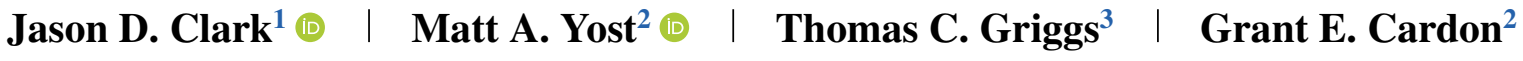 \\ Corey V. Ransom ${ }^{2} \quad$ J. Earl Creech ${ }^{2}$ (c)
}

${ }^{1}$ South Dakota State Univ., 1148 Medary Ave., Brookings, SD 57007, USA

${ }^{2}$ Utah State Univ., 4820 Old Main Hill, Logan, UT 84322, USA

${ }^{3}$ West Virginia Univ., P.O. Box 6108, Morgantown, WV 26506, USA

\section{Correspondence}

J. Earl Creech, Utah State Univ., 4820 Old

Main Hill, Logan, UT 84322, USA

Email address: earl.creech@usu.edu

Associate Editor: Anil Shrestha

\begin{abstract}
Tillage type/timing and herbicide application date may change the amount and timing of $\mathrm{N}$ mineralization, altering fertilizer $\mathrm{N}$ needs for first-year corn (Zea mays $\mathrm{L}$.) following glyphosate [N-(phosphonomethyl)glycine]-resistant (GR) alfalfa (Medicago sativa L.). Studies were conducted in 2012 and 2013 in Utah. Yield, quality, and economic return of silage corn as affected by five tillage type/timings (fall conventional till, spring conventional till, fall strip-till, spring strip-till, and no-till), three herbicide application dates for alfalfa termination (fall, spring, and in-crop), and four $\mathrm{N}$ rates $\left(0,56,112\right.$, and $\left.224 \mathrm{~kg} \mathrm{ha}^{-1}\right)$ were evaluated. Silage corn yield and quality following GR alfalfa was economically optimized without $\mathrm{N}$ fertilization regardless of tillage type/timing and herbicide application date. Thus, $\mathrm{N}$ from decomposing alfalfa can provide the full $\mathrm{N}$ requirement of first-year silage corn following GR alfalfa. Estimated animal milk production $\mathrm{ha}^{-1}$ of silage corn was greatest and similar for all herbicide application dates with conventional tillage and spring herbicide application with strip-till and no-till (26-38 $\mathrm{Mg}$ milk ha $^{-1}$ ), whereas an in-crop herbicide application with strip-till and no-till resulted in the lowest estimated milk production (21-29 $\mathrm{Mg}$ milk ha $^{-1}$ ). Increased economic return for the in-crop herbicide date by including economics from harvesting the first alfalfa cutting before planting corn mostly offset the reduced economic return of the lower silage corn yield. Therefore, an application of 2,4-D (2,4-dichlorophenoxyacetic acid) and dicamba (3,6-dichloro2-methoxybenzoic acid) in the fall, spring, or in-crop to control GR alfalfa are good economic options for conventional tillage, strip-till, and no-till systems.
\end{abstract}

\section{1 | INTRODUCTION}

Corn (Zea mays L.) following alfalfa (Medicago sativa L.) in rotation is a common practice in dairy production areas of

Abbreviations: aNDF, amylase treated neutral detergent fiber; $\mathrm{CP}$, crude protein; DM, dry matter; dNDF48, digestibility of neutral detergent fiber at $48 \mathrm{~h}$; GR, glyphosate-resistant; IVTDMD48, in vitro true dry matter digestibility at $48 \mathrm{~h}$; NDFD48, neutral detergent fiber digestibility at $48 \mathrm{~h}$; $\mathrm{NE}_{\mathrm{L}}-3 \mathrm{x}$, net energy for lactation at $3 \times$ maintenance intake

(c) 2021 The Authors. Agronomy Journal @ 2021 American Society of Agronomy the United States. Herbicide application, tillage, or a combination of both is commonly used to terminate an alfalfa stand and prepare the soil for corn planting. The decomposing alfalfa may supply $\mathrm{N}$ to the following corn crop. However, the amount and timing of mineralization may differ based on alfalfa stand age and method and time of year alfalfa is terminated along with the environmental conditions during the growing season. Soil factors such as quantity, quality, and accessibility of organic $\mathrm{N}$, along with temperature and 
moisture determine the amount of $\mathrm{N}$ mineralized in a growing season (Blagodatskaya \& Kuzyakov, 2008; Kuzyakova, Turyabahika, \& Stahr, 2006; Sierra, 1992; Wu, Ma, \& Liang, 2008).

The date of alfalfa termination and the method used (i.e., herbicides, tillage, or a combination of both) has the potential to influence the amount and timing of $\mathrm{N}$ mineralization. Conventional tillage practices (moldboard plow, subsoiler, disk) incorporate plant residues into the soil, increasing $\mathrm{N}$ mineralization and subsequent soil $\mathrm{N}$ compared with conservation tillage practices like strip-till and no-till (Malhi et al., 2007; Malhi, Lemke, \& Schoenau, 2009; Mohr, Entz, Janzen, \& Bullied, 1999; Moyer, Clapperton, \& Boswall, 2003). Growers are transitioning from conventional to conservation tillage practices to maintain soil structure, decrease erosion (Moyer et al., 2003), retain soil moisture, and decrease $\mathrm{NO}_{3}{ }^{-}-\mathrm{N}$ leaching (Malhi et al., 2009). Because more of the top growth of alfalfa is left on the soil surface of these systems, $\mathrm{N}$ mineralization is delayed (Mohr, Janzen, Bremer, \& Entz, 1998). This delay decreases the short-term N supply (Mohr et al., 1999; Moyer et al., 2003; Sainju \& Singh, 2001). Research conducted in Minnesota reported that no-till and conventional tillage systems can economically optimize first-year silage corn yield following alfalfa without additional fertilizer $\mathrm{N}$ (Yost, Coulter, \& Russelle, 2013; Yost, Coulter, Russelle, Sheaffer, \& Kaiser, 2012; Yost, Russelle, \& Coulter, 2013). This is similar to other findings in the U.S. Midwest and New York in conventional tillage systems, where little $(\leq 40 \mathrm{~kg} \mathrm{~N}$ $\mathrm{ha}^{-1}$ ) to no $\mathrm{N}$ fertilizer was normally needed for economically optimal first-year silage corn yield (Basso \& Ritchie, 2005; Lawrence, Ketterings, \& Cherney, 2008; Rasse, Ritchie, Peterson, Loudon, \& Martin, 1999). However, information is needed regarding fertilizer $\mathrm{N}$ needs of strip-till systems in comparison to no-till and conventional tillage.

The time of year alfalfa is terminated can also affect the amount and timing of available $\mathrm{N}$ in the soil. Alfalfa is typically terminated with tillage and/or an application of glyphosate [N-(phosphonomethyl) glycine] in the fall or spring. However, the planting of glyphosate-resistant (GR) alfalfa has resulted in the use of other herbicides to terminate alfalfa. One effective herbicide choice has been a mixture of 2,4-D (2,4-dichlorophenoxyacetic acid) plus dicamba (3,6dichloro-2-methoxybenzoic acid) (Van Deynze et al., 2004). This new herbicide combination requires a change in application timings compared with glyphosate due to herbicide label restrictions on feeding of sprayed crops and timing of subsequent tilling and planting. For non-GR alfalfa, alfalfa can be terminated by an application of glyphosate once alfalfa reaches $10-15 \mathrm{~cm}$ of regrowth. However, it is typically terminated by an application of glyphosate made $36 \mathrm{~h}$ before alfalfa harvest, after which tillage and corn planting can immediately occur (Monsanto, 2019). This practice cannot be used with an application of 2,4-D or dicamba alone or in combination. For

\section{Core Ideas}

- Decomposition of alfalfa provided full $\mathrm{N}$ requirement of silage corn regardless of tillage system.

- Terminating glyphosate-resistant alfalfa in the spring optimized silage corn quality with strip-till and no-till.

- Silage corn quality was similar with conventional tillage regardless of herbicide application date.

- Terminating alfalfa after corn emergence reduced estimated milk production from silage corn.

- Profit was similar for all herbicide timings when including revenue from corn and alfalfa.

these herbicides, application must wait until alfalfa has been harvested and regrowth has reached $10-15 \mathrm{~cm}$. Then tillage and planting must be delayed another $7-14 \mathrm{~d}$ so that the herbicides can sufficiently translocate throughout the plant for maximum alfalfa termination and minimized corn injury risk (BASF, 2010; Winfield, 2020).

The date of alfalfa stand removal requires a balance between effectively terminating the alfalfa stand while protecting silage corn yield. Previous research in Canada, New York, and Idaho reported both fall and spring alfalfa termination dates for non-GR alfalfa have resulted in sufficient mineralized $\mathrm{N}$ to economically optimize silage corn yield without N fertilization (Aflakpui et al., 1994; Carter, Berg, \& Sanders, 1991; Lawrence et al., 2008). However, it is unknown whether the same holds true for the later fall and spring dates used with GR alfalfa. Additionally, some alfalfa growers use a doublecropping system where they wait to plant corn until after harvesting the first cutting of alfalfa in the spring. Harvesting GR alfalfa in this system and waiting for sufficient regrowth before applying herbicides and waiting another 7-14 $\mathrm{d}$ before tilling and planting often reduces the growing season length and silage corn yield (Darby \& Lauer, 2002; Van Roekel \& Coulter, 2011). In this situation, a potential alternative would be to harvest GR alfalfa, complete tillage practice, plant corn immediately, and then terminate GR alfalfa after corn emergence and sufficient alfalfa regrowth occurs. This alternative lengthens the corn growing season. However, the effect of these later fall, spring, and in-crop herbicide applications on fertilizer- $\mathrm{N}$ rate needed to economically optimize silage corn yield and quality compared with a traditional fall or preplant spring herbicide application is unknown.

Most studies on first-year corn following alfalfa have focused on grain yield, with relatively few on silage corn yield. Nutritional value parameters like crude protein (CP), amylase-treated neutral detergent fiber (aNDF), and starch are also of particular importance when growing silage corn. In 
New York, these nutritional parameters were reported to be more responsive to $\mathrm{N}$ management than yield-fertilizer- $\mathrm{N}$ rate needed for highest forage quality was at least $50 \mathrm{~kg} \mathrm{~N}$ $\mathrm{ha}^{-1}$ greater than that needed for maximum dry matter (DM) yield (Cox, Kalonge, Cherney, \& Reid, 1993). Further, a study with 10 site-years in Minnesota on silt loam and sandy loam soils and 13 site-years in New York reported $\mathrm{N}$ fertilization increased CP but had an inconsistent effect on other forage quality variables (Lawrence et al., 2008; O'Leary \& Rehm, 1990). Further, silage corn quality after GR alfalfa may also be influenced by different tillage systems and the later fall, spring, and in-crop herbicide application dates required when using growth regulator herbicides.

Silage corn growers need more information on how different termination methods of GR alfalfa affect fertilizer-N requirements to economically optimize both silage corn yield and quality. Improving fertilizer-N guidelines for silage corn yield and quality following GR alfalfa could improve economic returns for growers and reduce potential $\mathrm{N}$ losses to the environment. Therefore, the objective of this research was to compare yield, quality, and economic return of silage corn as influenced by $\mathrm{N}$ rates, tillage method (conventional, striptill, and no-till), and herbicide application date (fall, spring, and in-crop after corn planting).

\section{2 | MATERIALS AND METHODS}

\section{1 | Experimental design}

Field studies were conducted at sites with coarse-textured soil in Cornish and fine-textured soil in Cache Junction, UT, in 2012 and 2013, with a total of four site-years over the 2yr period. The soil texture in Cornish in 2012 was a loamy fine sand (Layton, mixed, mesic Psammentic Haploxerolls) and in 2013 was a fine sandy loam (Kidman, coarse-loamy, mixed, superactive, mesic Calcic Haploxerolls). The soil texture in Cache Junction was a silty clay loam (Trenton, fine, mixed, superactive, mesic Typic Natrixerolls) in 2012 and 2013. Alfalfa fields were planted to GR varieties and had been in production for 5-7 yr. Studies were initiated in the fall of the last year the alfalfa stand was in production.

Treatments consisted of five tillage type/timing combinations (fall conventional tillage, spring conventional tillage, fall strip-till, spring strip-till, and no-till), three herbicide application dates to terminate GR alfalfa (fall, spring, and in-crop [after corn germination]), and four fertilizer- $\mathrm{N}$ rates $(0,56$, 112 , and $224 \mathrm{~kg} \mathrm{~N} \mathrm{ha}^{-1}$ ). The experimental design was a randomized complete block in a split-split plot arrangement with four replications. Whole plots consisted of the five tillage type/timing combinations and measured $3.0 \mathrm{~m}$ wide (four rows) and $122 \mathrm{~m}$ long in 2012 and $146 \mathrm{~m}$ long in 2013. Fall and spring tillage treatments were completed a minimum of
7-14 $\mathrm{d}$ after the fall and spring herbicide treatment following herbicide label guidelines. Conventional tillage was completed by subsoiling to a depth of $45 \mathrm{~cm}$ on $45-\mathrm{cm}$ centers (Model S207, Miskin), disking to a depth of $15 \mathrm{~cm}$ (Model 5815W, Kuhn Krause, Inc.), and roller harrowing (Brillion Farm Equipment Landoll Corp.) before planting. Strip-till was completed by tilling to a depth of $20 \mathrm{~cm}$ and a width of $25 \mathrm{~cm}$ using a two-row strip-till implement (Model 839-076 1 tRIPr, Orthman). Corn seed was planted directly into the strip-tilled area without further seedbed preparation. The no-till treatment received no tillage before planting.

Subplots consisted of the three herbicide application date treatments (fall, spring, and in-crop [after corn germination]) and measured $3 \mathrm{~m}$ wide and $31 \mathrm{~m}$ long in 2012 and $37 \mathrm{~m}$ long in 2013. The fall herbicide application date occurred between 4 and 15 October of each year. This was after the last alfalfa cutting when regrowth was sufficient for an effective herbicide response as described in BASF (2010) and Winfield (2020). Fall tillage operations occurred 7-14 d later. The spring herbicide application date was completed on $28 \mathrm{Apr}$. 2012 and 24 Apr. 2013, 2 wk before spring tillage operations. The in-crop herbicide application date occurred between 8 and 15 June 2012 in Cornish and Cache Junction, respectively, and on 17 June 2013 for both sites, 3-4 wk after tillage and corn planting when corn was at the V2 to V3 development stage (Abendroth, Elmore, Boyer, \& Marlay, 2011). This incrop herbicide application date simulated the practice of a farmer taking the first cutting of alfalfa in the spring, tilling (if used), planting corn immediately, and controlling the GR alfalfa 3-4 wk later. By this time, the corn was mature enough to avoid significant herbicide damage and the GR alfalfa had sufficient leaf area for an effective herbicide response. All herbicide date treatments were completed by applying a mixture of 2,4-D LV6 at $784 \mathrm{~g}$ a.e. ha ${ }^{-1}$, plus dicamba at $280 \mathrm{~g}$ a.e. $\mathrm{ha}^{-1}$, plus non-ionic surfactant at $0.25 \% \mathrm{v} / \mathrm{v}$ (BASF, 2010; Winfield, 2020). The herbicide mixture was applied with a $\mathrm{CO}_{2}$ pressurized backpack sprayer fitted with XR TeeJet 80015 nozzles spaced $38 \mathrm{~cm}$ apart and calibrated to deliver a spray volume of $140 \mathrm{~L} \mathrm{ha}^{-1}$ at $276 \mathrm{kPa}$ pressure. Before each herbicide application date, the range in alfalfa regrowth stem height was determined. This was done by averaging alfalfa stem height from the soil to the highest true alfalfa leaves of all alfalfa plants within $1 \mathrm{~m}^{2}$ of a meter stick in the center of each herbicide date subplot (Table 1).

Sub-subplots consisted of the four fertilizer-N rates and measured $3.0 \mathrm{~m}$ wide and $8 \mathrm{~m}$ long in 2012 and $9 \mathrm{~m}$ long in 2013. Nitrogen rate treatments of $0,56,112$, or $224 \mathrm{~kg}$ $\mathrm{N} \mathrm{ha}^{-1}$ were applied within $7 \mathrm{~d}$ after planting and immediately sprinkle-irrigated with approximately $25 \mathrm{~mm}$ of water to incorporate the fertilizer. Nitrogen was broadcast applied using liquid urea-ammonium nitrate $\left(320 \mathrm{~g} \mathrm{~N} \mathrm{~kg}^{-1}\right)$. All other nutrient and $\mathrm{pH}$ deficiencies were corrected before planting 
T A B L E 1 Alfalfa stand age, plant population, and stem height before each herbicide application date at Cornish (coarse-textured soil) and Cache Junction, UT (fine-textured soil) in 2012 and 2013

\begin{tabular}{|c|c|c|c|c|c|}
\hline \multirow[b]{3}{*}{ Site-year } & \multirow[b]{3}{*}{ Alfalfa stand age } & \multirow[b]{3}{*}{ Alfalfa plant population } & \multicolumn{3}{|c|}{ Alfalfa stem height ${ }^{\mathrm{a}}$} \\
\hline & & & \multicolumn{3}{|c|}{ Herbicide application dates } \\
\hline & & & Fall & Spring & In-crop \\
\hline Cornish-2012 & 7 & $34-58$ & $15-45$ & $15-20$ & $15-20$ \\
\hline Cache Junction-2012 & 5 & $52-106$ & $30-45$ & $15-20$ & $20-25$ \\
\hline
\end{tabular}

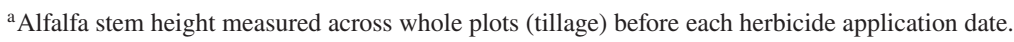

following university guidelines to maximize silage corn production (James \& Topper, 2010).

A four-row no-till precision vacuum planter (Model NG Plus 4, Monosem Inc.) was used to plant GR corn (Dekalb hybrid DKC 55-24, Monsanto) 5-cm deep in 76-cm rows at 93,860 seeds $\mathrm{ha}^{-1}$. Cornish was planted on 12 May 2012 and 24 May 2013. Cache Junction was planted on 21 May 2012 and 17 May 2013. At corn planting, weeds were controlled with an application of acetochlor (2-chloro-2'-methyl$6^{\prime}$-ethyl-N-ethoxymethylacetanilide) at $1,789 \mathrm{~g}$ a.i. $\mathrm{ha}^{-1}$ plus paraquat (1,1'dimethyl-4,4'-bipyridinium dichloride) at $841 \mathrm{~g}$ cation $\mathrm{ha}^{-1}$ and non-ionic surfactant at $0.25 \% \mathrm{v} / \mathrm{v}$ at a spray volume of $187 \mathrm{~L} \mathrm{ha}^{-1}$.

\section{2 | Plant sampling and analysis}

Final alfalfa stand population was determined by counting the number of crowns inside two $0.5-\mathrm{m}^{2}$ quadrats per replication. Aboveground silage yield was measured by harvesting the center two rows of each sub-subplot with a two-row pull-behind silage corn chopper (Model 865, Gehl). Silage corn was blown into a weigh bin mounted on load cells that weighed each plot. A 1-kg subsample was collected to determine moisture and quality. Each sample was weighed, dried at $60{ }^{\circ} \mathrm{C}$ in a forced-air oven until constant mass, and weighed again to determine DM yield. Silage corn samples were ground through a cutting mill (Wiley Mod. 3, Thomas Scientific) with a $2-\mathrm{mm}$ screen, repeatedly passed through a splitter until reduced to $50 \mathrm{~g}$, and ground through a cyclone mill (Udy Corp.) with a 1-mm screen. Silage corn nutritional value parameters of $\mathrm{CP}$, amylase-treated neutral detergent fiber (aNDF), in vitro true DM digestibility at $48 \mathrm{~h}$ (IVTDMD48), starch, and digestible neutral detergent fiber at $48 \mathrm{~h}$ (dNDF48) were determined by scanning samples with a near-infrared reflectance spectrophotometer (Model 6500, FOSS NIRSystems, Inc.) and WinISI software (v. 4.5, Infrasoft International LLC, Port). Reflectance data were obtained at 2-nm increments between 1,100 and 2,498 $\mathrm{nm}$. Sample composition was predicted with the 2012 unfermented silage corn equation (12UCS50-2.eqa) developed by the NIRS Forage and Feed Testing Consortium according to procedures of Shenk and Westerhaus (1991). The equation calibration set of 211-235 samples included 17 selected from Utah silage corn trials over multiple genotypes, sites, and years. The distribution and boundaries of all sample spectra were well represented by the population structure of spectra in the calibration set, falling within acceptance criteria of global $\mathrm{H}$ and neighborhood $\mathrm{H}$ distances of $\leq 3.0$ and 1.2, respectively. Standard errors of cross-validation for NIRS prediction from modified partial least squares regression were $6,15,22,17$, and $22 \mathrm{~g} \mathrm{~kg}^{-1} \mathrm{DM}$, respectively, for CP, aNDF, IVTDMD48, starch, and dNDF48. Proportions of variation in CP, aNDF, IVTDMD48, starch, and dNDF48 concentrations in calibration samples accounted for by NIRS-predicted values were $.88, .97, .80, .98$, and .85 , respectively. Crude protein, aNDF, NDFD48 (calculated from dNDF48), starch, constants for fat and ash, and DM yield were used in the MILK2006 spreadsheet developed at the University of Wisconsin to calculate net energy for lactation at $3 \mathrm{x}$ maintenance intake $\left(\mathrm{NE}_{\mathrm{L}}-3 \mathrm{x}\right)$ and milk ha ${ }^{-1}\left(\mathrm{Mg} \mathrm{milk} \mathrm{ha}^{-1}\right.$ silage corn DM) (Shaver, 2007; Shaver, Hoffman, Lauer, \& Coors [n.d.]).

The economic return for silage corn was determined by subtracting field operation costs (tillage, herbicide, $\mathrm{N}$, and alfalfa harvest for the in-crop herbicide date) from revenue sources (silage corn and the first alfalfa cutting for the incrop herbicide date). A silage corn price of US $\$ 151 \mathrm{Mg}^{-1}$ DM was determined with the equation described in Feuz, Israelsen, Young, and Holmgren (2012) using the 5-yr average alfalfa hay price of US $\$ 150 \mathrm{Mg}^{-1}$ (USDA-NASS, 2020). Due to the proximity of the field sites to Idaho, tillage, herbicide, $\mathrm{N}$ application, and alfalfa harvest costs were determined using custom rates from Idaho (Patterson \& Painter, 2015). The average cost of $\mathrm{N}$ fertilizer (US\$0.93 $\mathrm{kg}^{-1}$ ) was used to calculate the cost of each fertilizer-N rate (USDA-ERS, 2019). Chemical costs were based on current market value and amounts used (Intermountain Farmer's Association, personal communication, 2014). 
TA B L E 2 Degrees of freedom, F-value, and significance level for the effects of site-year, tillage, herbicide date, fertilizer-N rate, and their interactions for silage corn dry matter (DM) yield and quality measurements for Cornish (coarse-textured soil) and Cache Junction, UT (fine-textured soil) in 2012 and 2013

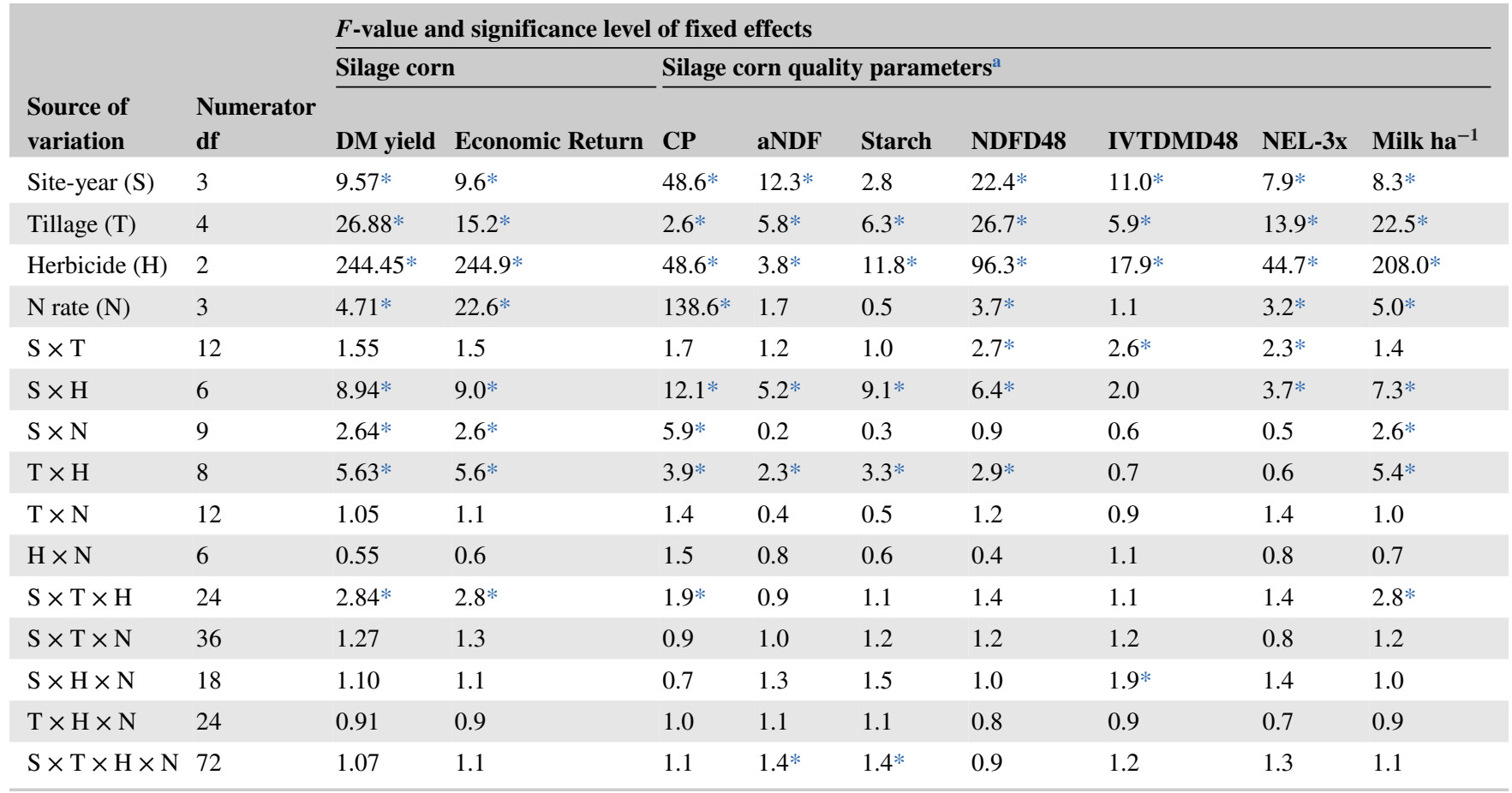

${ }^{a}$ aNDF, amylase-treated neutral detergent fiber; CP, crude protein; IVTDMD48, in vitro true dry matter digestibility at 48 h; NDFD48, neutral detergent fiber digestibility at $48 \mathrm{~h} ; \mathrm{NE}_{\mathrm{L}}-3 \mathrm{x}$, net energy for lactation at $3 \mathrm{x}$ maintenance intake.

*Significant at the .05 probability level.

\section{3 | Statistical analysis}

Silage corn DM yield, quality measurements, and economic return were evaluated using PROC MIXED in SAS 9.4 (SAS Institute Inc.) (Littell, Milliken, \& Stroup, 1996). Residual plots showed normality and constant variance assumptions were met. Site-year, tillage, herbicide application date, $\mathrm{N}$ rate, and their interactions were considered fixed effects; block and interactions with block were considered random effects. When the main effect of $\mathrm{N}$ rate or its interactions with other fixed effects were significant, silage corn yield, quality measurements, and economic return were regressed to fit linear, quadratic, linear-plateau, and quadratic-plateau models using PROC REG and PROC NLIN (Cerrato \& Blackmer, 1990; Scharf et al., 2005). Models were compared using the metrics of model probability significance and coefficient of determination, and the best fit model among the four was selected separately for each dependent variable. When $\mathrm{N}$ rate was significant in the ANOVA model and no regression models were significant $(P \geq .05)$, the LSMeans procedure with the Tukey method to adjust for multiple comparisons was used to determine differences among treatment least square means.

Three or four-way interactions involving $\mathrm{N}$ rate were only significant for silage corn quality parameters: aNDF, starch, and IVTDMD48 (Table 2). In these three cases, the effect of $\mathrm{N}$ rate was minimal and not consistent. Therefore, we also evaluated the next highest order interaction for each main effect that did not contain $\mathrm{N}$ rate. Mean separation between tillage method, herbicide application date, site-year, and their interactions were completed using the LSMeans procedure with the Tukey method to adjust for multiple comparisons.

\section{3 | RESULTS AND DISCUSSION}

\section{1 | Fertilizer $\mathbf{N}$ effect on silage corn yield}

Silage corn DM yield was between 19.7 and 24.6 $\mathrm{Mg} \mathrm{ha}^{-1}$ across the four site-years and was influenced by the site $\times \mathrm{N}$ rate interaction (Tables 2 and 3). This was the only significant interaction that involved fertilizer-N rate, and it was minor in magnitude. In three of the four site-years, silage corn yield did not increase with greater $\mathrm{N}$ rates (Table 3). At the finetextured site-year in 2013 (Cache Junction), silage corn yield was slightly higher at 56 compared with $0 \mathrm{~kg} \mathrm{~N} \mathrm{ha}^{-1}$, but the 0,112 , and $224 \mathrm{~kg} \mathrm{~N} \mathrm{ha}^{-1}$ rates were similar. Therefore, there was no consistent benefit to silage corn yield from fertilizer $\mathrm{N}$ addition at any of the four site-years. These results indicate 
T A B L E 3 Silage corn dry matter yield and estimated amount of milk ha ${ }^{-1}$ from silage corn as influenced by fertilizer-N rate averaged across five tillage treatments and three herbicide application timings at Cornish (coarse-textured soil) and Cache Junction, UT (fine-textured soil) in 2012 and 2013

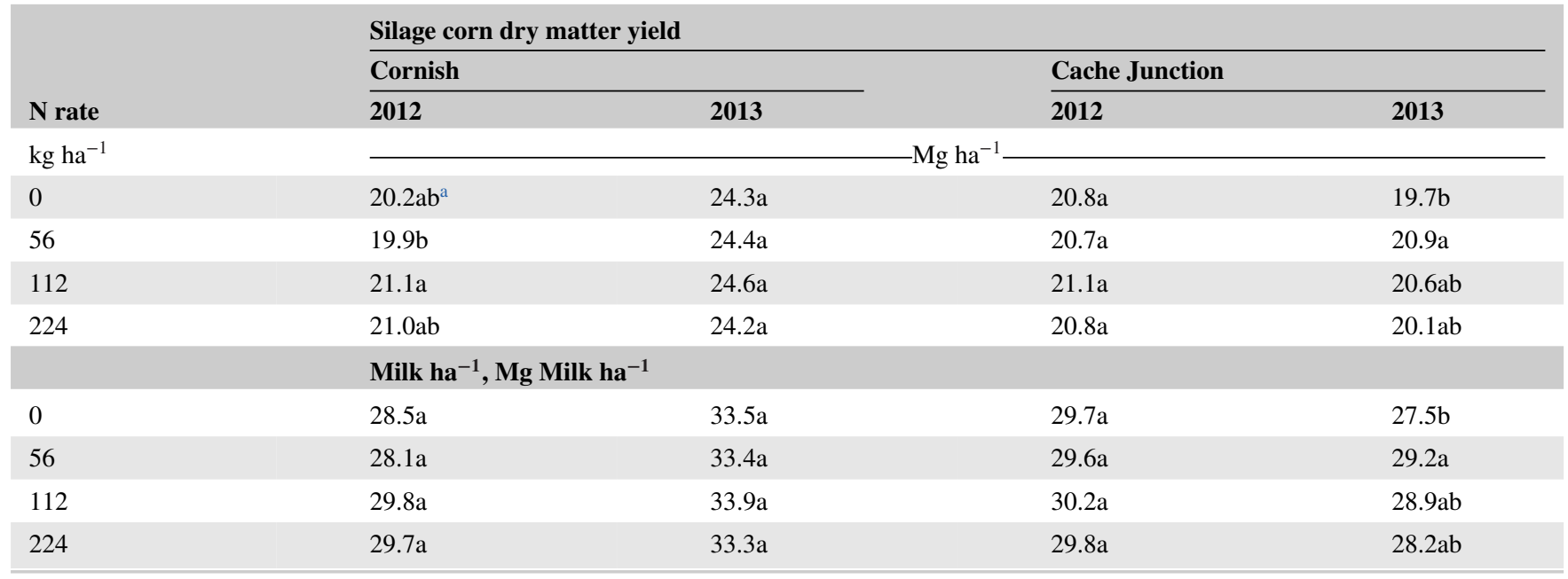

${ }^{a}$ Means with different letters in the same column are statistically different $(P \leq .05)$.

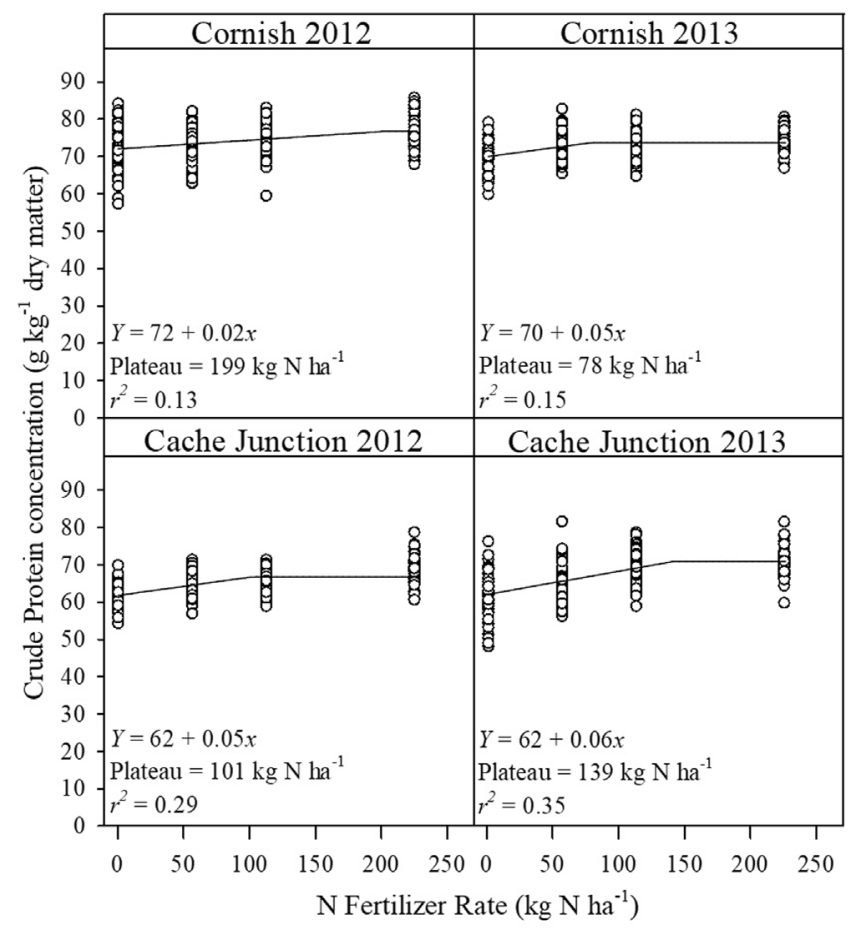

F I G U R E 1 Silage corn crude protein concentration as influenced by fertilizer-N rate averaged across five tillage treatments and three herbicide application timing treatments used to terminate the previous alfalfa stand at Cornish, UT (coarse-textured soils) and Cache Junction, UT (fine-textured soil) in 2012 and 2013

plant available $\mathrm{N}$ and $\mathrm{N}$ from mineralization after terminating GR alfalfa can provide the full amount of $\mathrm{N}$ required for firstyear silage corn regardless of herbicide application date (fall, spring, or in-crop) and tillage type/timing used (fall or spring conventional tillage, fall or spring strip-till, or no-till).
Few studies have evaluated the effect of GR alfalfa termination strategies on the response of silage corn to fertilizer $\mathrm{N}$ addition. However, non-GR alfalfa adequately terminated with combinations of tillage, herbicides, or a combination of both also supplied all the $\mathrm{N}$ required for optimal silage corn yield in four site-years in Michigan (Basso \& Ritchie, 2005; Rasse \& Smucker, 1999), 13 site-years in New York (Lawrence et al., 2008), five site-years in Idaho (Carter et al., 1991), and 25 site-years in Minnesota (Yost et al., 2012; Yost, Coulter, \& Russelle, 2013; Yost, Russelle, \& Coulter, 2013). When $\mathrm{N}$ fertilization was needed in these studies to economically optimize silage corn yield, a small application of $\leq 40 \mathrm{~kg} \mathrm{~N} \mathrm{ha}^{-1}$ was all that was needed, except for three siteyears in Minnesota that required $113 \mathrm{~kg} \mathrm{~N} \mathrm{ha}^{-1}$ (Yost, Russelle, \& Coulter, 2013). Using 259 site-years of data mostly from the U.S. Midwest, Yost, Russelle, and Coulter (2014) determined that first-year corn after alfalfa is more likely to respond to $\mathrm{N}$ fertilization on coarse- compared with fine- and medium-textured soils. Other factors that helped improve the accuracy of identifying the likelihood of first-year corn after alfalfa responding to $\mathrm{N}$ fertilization included alfalfa termination time, alfalfa stand age, and weather conditions from October through spring. To determine if these same soil and weather factors can be used to determine the likelihood of $\mathrm{N}$ fertilization for first-year corn following alfalfa in the U.S. Intermountain West, more than our current four site-years of data are needed.

\section{2 | Fertilizer $\mathbf{N}$ effect on silage corn quality}

The impact of $\mathrm{N}$ fertilizer varied greatly by silage corn quality parameter (Table 2). Crude protein, aNDF, and starch 


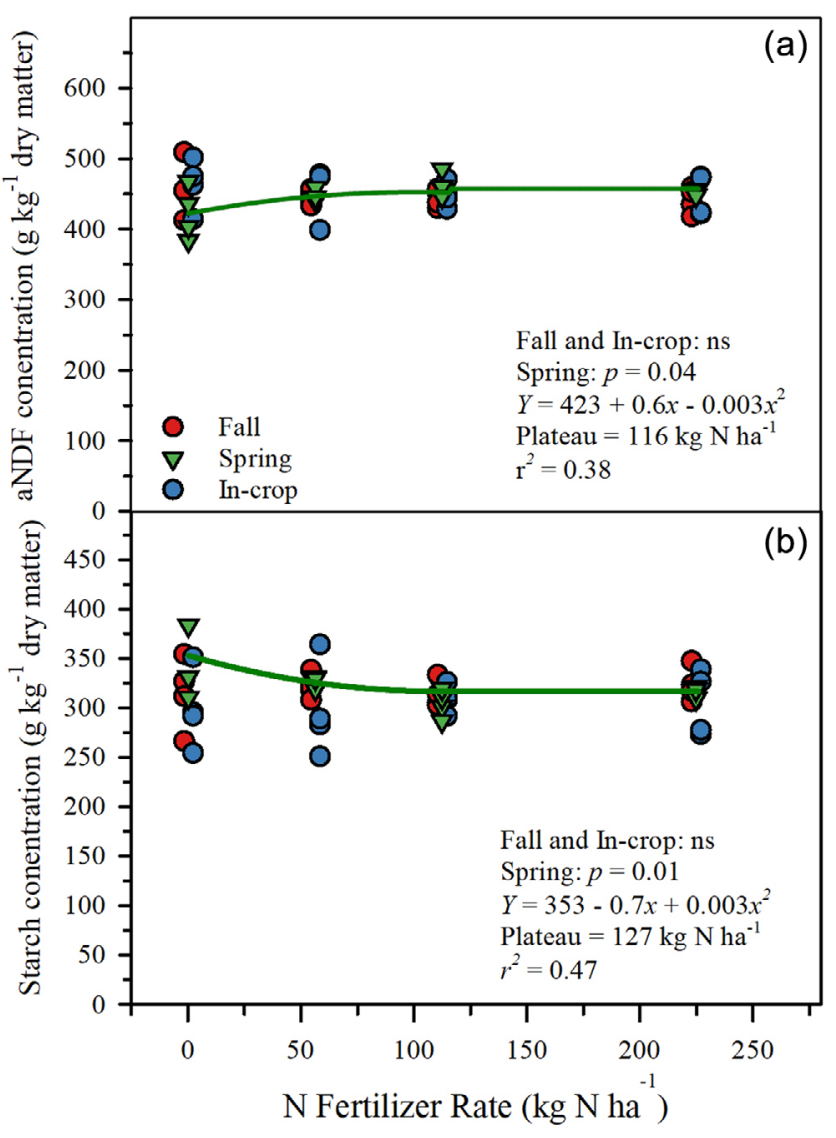

F I G U R E 2 Silage corn (a) amylase-treated neutral detergent fiber (aNDF) and (b) starch concentration as influenced by herbicide application timing to terminate the previous alfalfa stand (fall, spring, and in-crop) and fertilizer-N rate in no-till at the Cornish 2013 site-year only. All other tillage type/timing (no-till, fall conventional tillage [Fall $\mathrm{CT}$ ], spring conventional tillage [Spring CT], fall strip-till, and spring strip-till) and herbicide application dates at Cornish (coarse-textured soils) and Cache Junction, UT (fine-textured soil) in 2012 and $2013 \mathrm{did}$ not respond to $\mathrm{N}$ fertilization $(P>.05)$. ns, sot significant

were the only quality parameters that consistently increased or decreased with increasing $\mathrm{N}$ rates (Figures 1 and 2). With increasing $\mathrm{N}$ rates, there was a linear-plateau relationship with $\mathrm{CP}$ at each site and a quadratic-plateau relationship with aNDF and starch for only the no-till and spring herbicide treatment at the coarse-textured site-year in 2013. Crude protein concentration increased with fertilizer $\mathrm{N}$ between 0.02 and $0.06 \mathrm{~g} \mathrm{~kg}^{-1} \mathrm{DM}$ per kilogram of additional fertilizer $\mathrm{N}$ up to between 78 and $199 \mathrm{~kg} \mathrm{~N} \mathrm{ha}^{-1}$ (Figure 1). In other studies in New York and Minnesota, CP also increased with fertilizer$\mathrm{N}$ rate (Cox et al., 1993; Lawrence et al., 2008). Amylasetreated neutral detergent fiber concentration increased with fertilizer by approximately $0.6 \mathrm{~g} \mathrm{~kg}^{-1} \mathrm{DM}$ per kilogram of additional fertilizer $\mathrm{N}$ up to $116 \mathrm{~kg} \mathrm{~N} \mathrm{ha}^{-1}$ (Figure 2). In contrast to these relationships, starch concentration had a negative quadratic-plateau relationship with increased fertil- izer $\mathrm{N}$, but only for the no-till and spring herbicide treatment at the coarse-textured site-year in 2013 (Figure 2). Starch decreased by approximately $0.7 \mathrm{~g} \mathrm{~kg}^{-1} \mathrm{DM}$ per kilogram of additional fertilizer $\mathrm{N}$ up to $127 \mathrm{~kg} \mathrm{~N} \mathrm{ha}^{-1}$. However, these changes in $\mathrm{CP}$, aNDF, and starch with increasing $\mathrm{N}$ rates were small. These low responses to fertilizer $\mathrm{N}$ were likely due to the high amount of $\mathrm{N}$ that was supplied to the corn from the decomposition of the previous alfalfa crop.

All other changes in silage corn quality parameters due to increased $\mathrm{N}$ rates were minimal and inconsistent (NDFD48, $\mathrm{NE}_{\mathrm{L}}-3 \mathrm{x}$ [Table 4], IVTDMD48 [Table 5]). Silage corn NDFD48 and $\mathrm{NE}_{\mathrm{L}}-3 \mathrm{x}$ were influenced by the site $\times \mathrm{N}$ rate interaction (Table 2). For NDFD48, the $0 \mathrm{~kg} \mathrm{~N}^{-1}$ rate was slightly higher than the 56 and $112 \mathrm{~kg} \mathrm{~N} \mathrm{ha}^{-1}$ rates, but the 0 and $224 \mathrm{~kg} \mathrm{~N}^{-1}$ rates were similar (Table 4). For $\mathrm{NE}_{\mathrm{L}^{-}}$ $3 \mathrm{x}$, the response at 224 was slightly higher than at $56 \mathrm{~kg} \mathrm{~N}$ $\mathrm{ha}^{-1}$, but the 0,112 , and $224 \mathrm{~kg} \mathrm{~N} \mathrm{ha}^{-1}$ rates were similar. Silage corn IVTDMD48 was influenced by the site $\times$ herbicide $\times \mathrm{N}$ rate interaction (Table 2). In three of four site-years, $\mathrm{N}$ rate did not affect IVTDMD48 (Table 5). At the coarsetextured site-year in 2012, only in the fall herbicide application date was IVTDMD48 slightly higher at 112 compared with $56 \mathrm{~kg} \mathrm{~N} \mathrm{ha}^{-1}$, but the 0,56 , and $224 \mathrm{~kg} \mathrm{~N} \mathrm{ha}^{-1}$ rates were similar.

Therefore, regardless of tillage type/timing and herbicide application timing, there was no consistent benefit of $\mathrm{N}$ fertilization for silage corn NDFD48, $\mathrm{NE}_{\mathrm{L}}-3 \mathrm{x}$, and IVTDMD48. These results are consistent with findings in New York and Minnesota, where $\mathrm{N}$ fertilization increased $\mathrm{CP}$ but only minimally effected other silage corn quality measurements (Cox et al., 1993; Lawrence et al., 2008; Sheaffer, Halgerson, \& Jung, 2006).

Ultimately, minimal changes in silage corn quality parameters due to $\mathrm{N}$ fertilization in conjunction with small differences in silage yield resulted in no differences in the estimated amount of animal milk produced per hectare of corn (milk $\mathrm{ha}^{-1}$ ) in three of the four site-years (Table 6). Similar to silage corn DM yield, at the coarse-textured site-year in 2012 (Cornish), the milk ha ${ }^{-1}$ value was slightly higher at 56 compared with $0 \mathrm{~kg} \mathrm{~N} \mathrm{ha}^{-1}$, but the 0,112 , and $224 \mathrm{~kg} \mathrm{~N} \mathrm{ha}^{-1}$ rates were similar. Further, this $1.7 \mathrm{Mg}$ milk ha ${ }^{-1}$ increase with an additional $56 \mathrm{~kg} \mathrm{~N} \mathrm{ha}^{-1}$ was small. If the average price received for milk was US $\$ 0.40 \mathrm{~kg}^{-1}$ (USDA-NASS, 2020) and the cost of $\mathrm{N}$ fertilizer was US $\$ 0.93 \mathrm{~kg}^{-1}$ (not including application cost), the economic return would have been a loss of US $\$ 51.40 \mathrm{ha}^{-1}$. Therefore, these results indicate that yield and quality of first-year silage corn grown in rotation with GR alfalfa was economically optimized without additional fertilizer $\mathrm{N}$ regardless of tillage type/timing and herbicide application date. 
T A B L E 4 Silage corn quality parameters of digestibility of neutral detergent fiber at $48 \mathrm{~h}$ (NDFD48) and net energy for lactation at 3x maintenance intake $\left(\mathrm{NE}_{\mathrm{L}}-3 \mathrm{x}\right)$ as influenced by fertilizer- $\mathrm{N}$ rate averaged across three herbicide application dates, five tillage treatments and four site-years

\begin{tabular}{|c|c|c|}
\hline $\mathrm{N}$ rate & NDFD48 & $N_{E}-3 x$ \\
\hline $\mathrm{kg} \mathrm{ha}^{-1}$ & $\mathrm{~g} \mathrm{~kg}^{-1} \mathrm{NDF}$ & Mcal kg ${ }^{-1} \mathrm{DM}$ \\
\hline 0 & $645 a^{a}$ & $1.378 \mathrm{ab}$ \\
\hline 112 & $641 b$ & $1.379 \mathrm{ab}$ \\
\hline 224 & $642 \mathrm{ab}$ & $1.381 \mathrm{a}$ \\
\hline
\end{tabular}

${ }^{a}$ Means with different letters in the same column are statistically different $(P \leq .05)$. DM, dry matter.

TA B L E 5 Silage corn quality parameter of in vitro true dry matter digestibility at $48 \mathrm{~h}$ as influenced by fertilizer-N rate within three herbicide application dates to terminate the previous alfalfa stand averaged across five tillage treatments at Cornish (coarse-textured soil) and Cache Junction, UT (fine-textured soil) in 2012 and 2013

\begin{tabular}{|c|c|c|c|c|}
\hline \multirow[b]{2}{*}{$\mathrm{N}$ rate } & \multicolumn{2}{|c|}{ Cornish } & \multicolumn{2}{|c|}{ Cache Junction } \\
\hline & 2012 & 2013 & 2012 & 2013 \\
\hline $\mathrm{kg} \mathrm{ha}^{-1}$ & \multicolumn{4}{|c|}{$\longrightarrow \mathrm{g} \mathrm{kg}^{-1} \mathrm{DM}$} \\
\hline 0 & $838 a^{a}$ & $834 a$ & $834 \mathrm{a}$ & $846 \mathrm{a}$ \\
\hline 56 & $828 b$ & $831 \mathrm{a}$ & $835 \mathrm{a}$ & $844 a$ \\
\hline 224 & $837 \mathrm{ab}$ & $829 a$ & $838 \mathrm{a}$ & $847 \mathrm{a}$ \\
\hline \multicolumn{5}{|c|}{ Spring herbicide application } \\
\hline 0 & $832 a$ & $832 a$ & $836 \mathrm{a}$ & $837 \mathrm{a}$ \\
\hline 56 & $835 \mathrm{a}$ & $826 a$ & $839 \mathrm{a}$ & $839 a$ \\
\hline 112 & $832 a$ & $824 a$ & $837 \mathrm{a}$ & $839 a$ \\
\hline 56 & $841 \mathrm{a}$ & $836 a$ & $839 a$ & $844 a$ \\
\hline 112 & $836 \mathrm{a}$ & $837 \mathrm{a}$ & $843 a$ & $845 \mathrm{a}$ \\
\hline 224 & $836 \mathrm{a}$ & $840 \mathrm{a}$ & $843 a$ & $846 \mathrm{a}$ \\
\hline
\end{tabular}

${ }^{a}$ Means with different letters in the same column and herbicide date are statistically different $(P \leq .05)$.

\section{3 | Tillage method and herbicide date effect on silage corn quality}

Tillage system and herbicide date alone or their interaction had a significant effect on all silage corn quality parameters, but effects varied by parameter (Table 2). Crude protein and milk ha ${ }^{-1}$ were the only parameters influenced by the threeway interaction of site, tillage, and herbicide. All other parameters were influenced by either the interaction of tillage and herbicide (aNDF, starch, and NDFD48) or the site interactions with tillage or herbicide alone. Despite significance, many of the differences among site-years were minimal. For CP, generally the fall conventional tillage and fall herbicide consistently had the highest CP, whereas no-till was the lowest. The in-crop herbicide date generally had a lower $\mathrm{CP}$ value numerically but not statistically compared with the fall and spring application dates (Supplemental Table S1). Generally, aNDF, NDFD48, IVTDMD48, and $\mathrm{NE}_{\mathrm{L}}-3 \mathrm{x}$ were consistently the greatest when tillage was combined with the in-crop herbicide date, followed by tillage systems combined with the fall and spring herbicide dates (Supplemental Tables S2-S4). The opposite was true for starch, where starch values were greatest for all tillage systems with fall or spring herbicide dates and when the in-crop herbicide date was used with fall or spring conventional tillage, whereas starch was lowest with strip-till and no-till when combined with an in-crop herbicide date (Supplemental Table S2). The treatments that frequently had the lowest yields (no-till and strip-till with in-crop herbicide date) consistently had greater aNDF, NDFD48, IVTDMD48, and $\mathrm{NE}_{\mathrm{L}}-3 \mathrm{x}$ values but lower starch values; the opposite was true 
T A B L E 6 Estimated Mg of milk ha ${ }^{-1}$ silage corn as influenced by tillage and herbicide application date to terminate the previous alfalfa stand averaged across four fertilizer-N rates at Cornish (coarse-textured soil) and Cache Junction, UT (fine-textured soil) in 2012 and 2013

\begin{tabular}{|c|c|c|c|c|c|}
\hline \multirow[b]{2}{*}{ Tillage $^{a}$} & \multirow[b]{2}{*}{ Herbicide } & \multicolumn{2}{|l|}{ Cornish } & \multicolumn{2}{|c|}{ Cache Junction } \\
\hline & & 2012 & 2013 & 2012 & 2013 \\
\hline & & \multicolumn{4}{|c|}{-Mg Milk ha ${ }^{-1}$} \\
\hline \multirow{2}{*}{ Fall CT } & spring & $32.6 \mathrm{a}$ & $38.1 \mathrm{a}$ & $33.1 \mathrm{a}$ & $30.4 \mathrm{abc}$ \\
\hline & in-crop & $28.4 \mathrm{abc}$ & $34.7 \mathrm{ab}$ & $28.4 \mathrm{bcdef}$ & $26.5 \mathrm{~cd}$ \\
\hline Spring CT & in-crop & $30.2 \mathrm{ab}$ & $33.1 \mathrm{bc}$ & $27.8 \mathrm{cdef}$ & $28.3 \mathrm{bcd}$ \\
\hline \multirow[t]{3}{*}{ Fall ST } & fall & $30.4 \mathrm{ab}$ & $32.1 \mathrm{bcd}$ & $26.9 \mathrm{ef}$ & $29.2 \mathrm{abc}$ \\
\hline & spring & $28.6 \mathrm{abc}$ & $36.1 \mathrm{ab}$ & $32.3 \mathrm{ab}$ & $31.1 \mathrm{ab}$ \\
\hline & in-crop & $21.6 \mathrm{~d}$ & $29.5 \mathrm{~cd}$ & $28.1 \mathrm{bcdef}$ & $21.1 \mathrm{e}$ \\
\hline \multirow[t]{3}{*}{ No-till } & fall & $29.5 \mathrm{ab}$ & $29.6 \mathrm{~cd}$ & $27.5 \mathrm{def}$ & 29.1abc \\
\hline & spring & $28.2 \mathrm{abc}$ & $35.7 \mathrm{ab}$ & 30.9abcde & $32.1 \mathrm{ab}$ \\
\hline & in-crop & $23.5 \mathrm{~cd}$ & $27.1 d$ & $26.2 \mathrm{f}$ & $21.4 \mathrm{e}$ \\
\hline
\end{tabular}

${ }^{\mathrm{a}} \mathrm{CT}$, conventional tillage; ST, strip-tillage.

${ }^{\mathrm{b}}$ Means with different letters in the same column are significantly different $(P \leq .05)$.

for the highest-yielding treatments (fall and spring herbicide date with all tillage treatments).

Herbicide date had a greater overall effect on silage corn quality parameters than tillage type/timing. Within each herbicide date, silage corn quality parameters were similar among the different tillage type and date treatments (Supplemental Tables S1-S4). Similar results were reported for a silt loam soil in Ontario, Canada, where no-till and conventional tillage practices combined with a spring herbicide application produced similar silage corn quality values (Aflakpui et al., 1994). These combined results indicate that silage corn quality in conservation tillage systems like no-till and strip-till can be similar to that of a conventional tillage system when comparing within the same herbicide application date.

Estimated milk production (Milk ha ${ }^{-1}$ ) ranged from 21.1 to $38.1 \mathrm{Mg}$ milk ha $^{-1}$ of silage corn across the four site-years and was influenced by the site $\times$ tillage $\times$ herbicide interaction (Tables 2 and 6). Generally, milk ha ${ }^{-1}$ decreased as tillage intensity decreased (moving from conventional- to strip- or no-till) and herbicide date moved from fall or spring to an incrop herbicide date. The highest milk ha ${ }^{-1}$ treatments were those combinations of fall and spring conventional tillage with fall, spring, or in-crop herbicide applications and fall and spring strip-till and no-till with fall or spring herbicide applications (26-38 Mg milk ha ${ }^{-1}$ ). However, the fall herbicide application date combined with no-till or fall or spring strip-till had lower milk ha ${ }^{-1}$ than fall or spring convention- ally tilled systems in two of the four site-years. The lowest milk ha ${ }^{-1}$ treatments were fall and spring strip-till and notill with the in-crop herbicide date $\left(21-29 \mathrm{Mg}\right.$ milk ha $\left.^{-1}\right)$. Fall versus spring tillage date did not affect milk ha ${ }^{-1}$ values at any of the herbicide dates for conventional or strip-till systems. These results indicate conservation tillage practices such as no-till and fall or spring strip-till can produce similar amounts of milk ha- ${ }^{-1}$ as conventional tillage. However, conservation tillage practices are more sensitive to the date of herbicide application. Their herbicide application should be completed in the spring to maximize milk ha ${ }^{-1}$, whereas herbicide application with fall and spring conventional tillage can be completed in the fall, spring, or in-crop. These results are similar to those reported for silage corn yield as discussed in Clark, Yost, Cardon, Ransom, and Creech (2020), where silage corn yield was maximized by terminating alfalfa with herbicides in a conventional tillage system in fall, spring, or in-crop and for a strip-till or no-till system in fall or spring (Table 6).

\subsection{Economic return}

Economic return across the four site-years ranged from US $\$ 2,297$ to US $\$ 4,085 \mathrm{ha}^{-1}$ (Table 7) and was influenced by the site $\times$ tillage $\times$ herbicide interaction (Table 2). Generally, the highest economic return was from combinations 
TA B L E 7 Economic return of silage corn dry matter when including the first cutting of alfalfa for the in-crop herbicide date as influenced by tillage and herbicide application date to terminate the previous alfalfa stand averaged across four fertilizer-N rates at Cornish (coarse-textured soil) and Cache Junction, UT (fine-textured soil) in 2012 and 2013

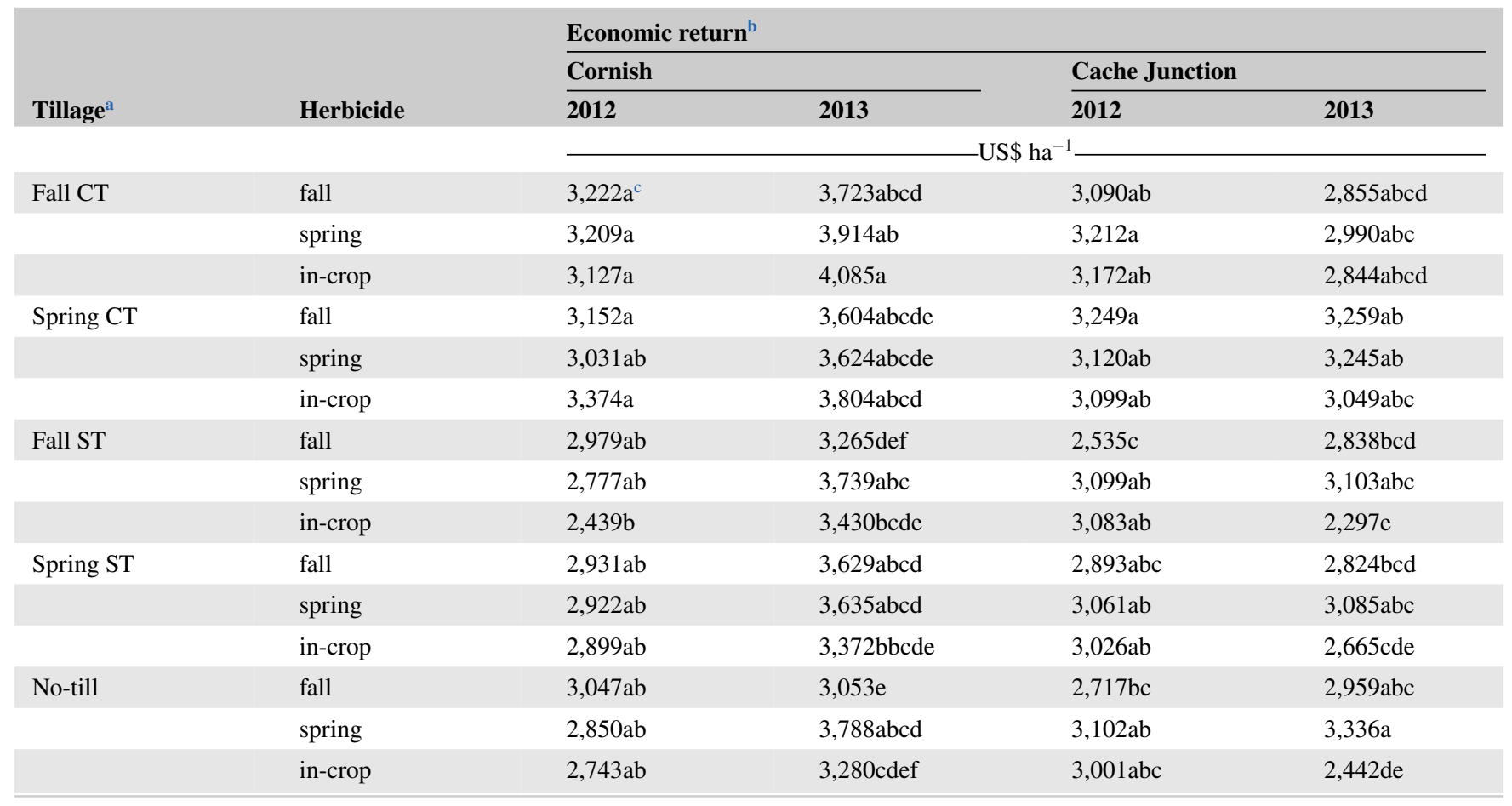

${ }^{\mathrm{a} C \mathrm{C}}$, conventional tillage; ST, strip-till.

${ }^{\mathrm{b}}$ Economic return $=$ Revenue $($ price of silage $\times$ yield + price of first alfalfa cutting $\times$ yield $)-$ Expenses $($ cost of tillage treatment + herbicide treatment $+\mathrm{N}$ fertilizer + alfalfa harvest).

${ }^{\mathrm{c}}$ Means with different letters in the same column are significantly different $(P \leq .05)$.

of fall and spring conventional tillage with fall, spring, or in-crop herbicide applications and fall and spring strip-till and no-till with a spring herbicide application (mean economic return $=$ US\$3,244). The lowest economic returns were from fall and spring strip-till and no-till with the fall and in-crop herbicide application date (mean economic return $=$ US\$2,799).

Herbicide date within each tillage type/timing treatment minimally affected economic return. In three of four siteyears, economic return was similar within each tillage type/timing regardless of herbicide date (Table 7). Herbicide application completed in-crop (V2 to V3 development stage of corn) compared with fall or spring reduced mean economic return between US $\$ 517$ and $\$ 894 \mathrm{ha}^{-1}$ at the fine-textured site-year in 2013 (Cache Junction) in only the fall strip-till and no-till systems. In most of the other fall and spring striptill and no-till treatments at the other three site-years, there was a trend for reduced economic profit when herbicide application was delayed until the in-crop date (mean reduction of US $\$ 227 \mathrm{ha}^{-1}$ ). This reduction in economic return was due to reduced silage corn yield from alfalfa competing with silage corn during the early season before the in-crop herbicide date was applied to terminate GR alfalfa (Clark et al., 2020). How- ever, this study indicates that, when economics from harvesting a first-alfalfa cutting in the spring and from silage corn are both considered, the reduced economic return from silage corn yield using an in-crop herbicide date is mostly offset. This makes the use of an in-crop herbicide application to control GR alfalfa after corn is planted a good economic option, especially in conventional tillage systems. If only the economic return from the silage corn is evaluated, then at two to three of the site-years economic return decreased significantly when using the in-crop herbicide date for all tillage systems (Supplemental Table S5). Therefore, it is important when calculating economic return to include both profit and expenses from the alfalfa and corn harvest to accurately compare economic return of each of these crop management systems.

\section{4 | CONCLUSIONS}

Silage corn yield, quality, and estimated milk production of first-year corn after GR alfalfa can be economically optimized with fall or spring conventional tillage and strip-till and notill regardless of fall, spring, or in-crop herbicide date with- 
out added fertilizer $\mathrm{N}$. These results provide evidence that the current $\mathrm{N}$ credit of $67-112 \mathrm{~kg} \mathrm{~N} \mathrm{ha}^{-1}$ given to alfalfa for first-year silage corn $\left(224 \mathrm{~kg} \mathrm{~N} \mathrm{ha}^{-1}\right.$ rate recommendation for a $20.7 \mathrm{Mg} \mathrm{ha}^{-1}$ yield) may be underestimated. Thus, the current recommendation needs to be reviewed and potentially updated in the Intermountain West. More site-years studying the effect of $\mathrm{N}$ fertilization on first-year corn after GR and non-GR alfalfa are needed under Intermountain West soils and weather conditions before an update can be completed.

Yield, quality, and economic return of silage corn can be maximized when non-glyphosate herbicides are applied to terminate GR alfalfa in the fall, spring, or in-crop using conventional tillage and in the spring when using strip-till and no-till. The ability to terminate alfalfa stands in the spring without reducing silage corn yield and quality allows growers to assess winterkill of alfalfa in the spring before deciding to terminate the alfalfa stand. In cropping systems where growers harvest the first cutting of GR alfalfa in the spring before planting corn and then control alfalfa after corn emergence, growers should expect a similar level of estimated milk production in a conventional tillage system but a reduction of $4.5-8.0 \mathrm{Mg}$ milk ha ${ }^{-1}$ of silage corn in a strip-till or no-till system. However, the reduced economic return from lower-yielding silage corn with an in-crop herbicide date is mostly offset when the economic return of the first cutting of alfalfa is included with the silage corn. This makes the use of an in-crop herbicide application to control GR alfalfa after corn is planted a good economic option, especially in conventional tillage systems.

\section{ACKNOWLEDGMENTS}

This research was supported by the Utah Agricultural Experiment Station, Utah State University, and approved as journal paper number 9384. We thank the USDA-NRCS Conservation Innovation Grant program for financial support.

\section{CONFLICT OF INTEREST}

The authors declare no conflict of interest.

\section{O R C I D}

Jason D. Clark (1) https://orcid.org/0000-0001-7793-6411 Matt A. Yost (10 https://orcid.org/0000-0001-5012-8481 J. Earl Creech 10 https://orcid.org/0000-0002-4393-6816

\section{R E F E R E N C E S}

Abendroth, L. J., Elmore, R. W., Boyer, M. J., \& Marlay, S. K. (2011). Corn growth and development. Ames: Iowa State University Extension.

Aflakpui, G., Vyn, T., Anderson, G., Clements, D., Hall, M., \& Swanton, C. (1994). Crop management systems for corn (Zea mays L.) following established alfalfa (Medicago sativa L.). Canadian Journal of Plant Science, 74(2), 255-259. https://doi.org/10.4141/cjps94-051

BASF. (2010). Clarity herbicide label. Retrieved from http://www.cdms. net/ldat/ld797012.pdf
Basso, B., \& Ritchie, J. T. (2005). Impact of compost, manure and inorganic fertilizer on nitrate leaching and yield for a 6-year maize-alfalfa rotation in Michigan. Agriculture, Ecosystems \& Environment, 108, 329-341. https://doi.org/10.1016/j.agee.2005.01.011

Blagodatskaya, E., \& Kuzyakov, Y. (2008). Mechanisms of real and apparent priming effects and their dependence on soil microbial biomass and community structure: Critical review. Biology and Fertility of Soils, 45(2), 115-131. https://doi.org/10.1007/ s00374-008-0334-y

Carter, D. L., Berg, R. D., \& Sanders, B. J. (1991). Producing no-till cereal or corn following alfalfa on furrow-irrigated land. Journal of Production Agriculture, 4, 174-179. https://doi.org/10.2134/jpa1991. 0174

Cerrato, M. E., \& Blackmer, A. M. (1990). Comparison of models for describing corn yield response to nitrogen fertilizer. Agronomy Journal, 82, 138-143. https://doi.org/10.2134/agronj1990. 00021962008200010030x

Clark, J. D., Yost, M. A., Cardon, G. E., Ransom, C. V., \& Creech, J. E. (2020). Tillage method and glyphosate-resistant alfalfa termination timing affect soil properties and subsequent corn yield. Agronomy Journal. https://doi.org/10.1002/agj2.20478 (in press).

Cox, W. J., Kalonge, S., Cherney, D. J. R., \& Reid, W. S. (1993). Growth, yield, and quality of forage maize under different nitrogen management practices. Agronomy Journal, 85, 341-347. https://doi.org/10. 2134/agronj1993.00021962008500020033x

Darby, H. M., \& Lauer, J. G. (2002). Planting date and hybrid influence on corn forage yield and quality. Agronomy Journal, 94(2), 281-289. https://doi.org/10.2134/agronj2002.0559

Feuz, D., Israelsen, C., Young, A., \& Holmgren, L. (2012). Buying and selling corn silage or other high moisture feeds: Value the feed not the water (AG/Agribusines/2012-02). Logan: Utah State University Extension.

James, D. W., \& Topper, K. F. (2010). Utah fertilizer guide (AG/431,1993). Logan: Utah State University Extension.

Kuzyakova, I. F., Turyabahika, F. R., \& Stahr, K. (2006). Time series analysis and mixed models for studying the dynamics of net $\mathrm{N}$ mineralization in a soil catena at Gondelsheim (S-W Germany). Geoderma, 136, 803-818. https://doi.org/10.1016/j.geoderma.2006.06.003

Lawrence, J. R., Ketterings, Q. M., \& Cherney, J. H. (2008). Effect of nitrogen application on yield and quality of silage corn after forage legume-grass. Agronomy Journal, 100(1), 73-79. https://doi.org/10. 2134/agronj2007.0071

Littell, R. C., Milliken, G. A., \& Stroup, W. W. (1996). SAS system for mixed models. Cary, NC: SAS Institute.

Malhi, S. S., Johnston, A. M., Loeppky, H., Vera, C. L., Beckie, H. J., \& Bandara, P. M. S. (2007). Immediate effects of time and method of alfalfa termination on soil mineral nitrogen, moisture, weed control, and seed yield, quality, and nitrogen uptake. Journal of Plant Nutrition, 30, 1059-1081. https://doi.org/10.1080/01904160701394501

Malhi, S. S., Lemke, R., \& Schoenau, J. J. (2009). Influence of time and method of alfalfa stand termination on yield, seed quality, $\mathrm{N}$ uptake, soil properties and greenhouse gas emissions under different $\mathrm{N}$ fertility regimes. Nutrient Cycling in Agroecosystems, 86, 17-38. https://doi.org/10.1007/s10705-009-9271-x

Mohr, R. M., Entz, M. H., Janzen, H. H., \& Bullied, W. J. (1999). Plantavailable nitrogen supply as affected by method and timing of alfalfa termination. Agronomy Journal, 91(4), 622-630. https://doi.org/10. 2134/agronj1999.914622x 
Mohr, R. M., Janzen, H. H., Bremer, E., \& Entz, M. H. (1998). Fate of symbiotically-fixed $15 \mathrm{~N} 2$ as influenced by method of alfalfa termination. Soil Biology and Biochemistry, 30, 1359-1367. https://doi.org/ 10.1016/S0038-0717(97)00267-8

Monsanto. (2019). Roundup PowerMAX herbicide label. Retrieved from http://www.cdms.net/ldat/ld8CC001.pdf

Moyer, J., Clapperton, M., \& Boswall, A. (2003). Method and time of alfalfa termination affects cereal growth and weed populations. Canadian Journal of Plant Science, 83, 969-976. https://doi.org/10.4141/ P02-186

O'Leary, M. J., \& Rehm, G. W. (1990). Nitrogen and sulfur effects on the yield and quality of corn grown for grain and silage. Journal of Production Agriculture, 3, 135-140. https://doi.org/10.2134/jpa1990. 0135

Patterson, P., \& Painter, K. (2015). Custom rates for Idaho agricultural operations. Moscow: University of Idaho Extension.

Rasse, D. P., Ritchie, J. T., Peterson, W. R., Loudon, T. L., \& Martin, E. C. (1999). Nitrogen management impacts on yield and nitrate leaching in inbred maize systems. Journal of Environmental Quality, 28, 13651371. https://doi.org/10.2134/jeq1999.00472425002800040042x

Rasse, D. P., \& Smucker, A. J. M. (1999). Tillage effects on soil nitrogen and plant biomass in a corn-alfalfa rotation. Journal of Environmental Quality, 28, 873-880. https://doi.org/10.2134/jeq1999. 00472425002800030019x

Sainju, U., \& Singh, B. (2001). Tillage, cover crop, and kill-planting date effects on corn yield and soil nitrogen. Agronomy Journal, 93, 878886. https://doi.org/10.2134/agronj2001.934878x

Scharf, P. C., Kitchen, N. R., Sudduth, K. A., Davis, J. G., Hubbard, V. C., \& Lory, J. A. (2005). Field-scale variability in optimal nitrogen fertilizer rate for corn. Agronomy Journal, 97, 452-461. https://doi. org/10.2134/agronj2005.0452

Shaver, R. D. (2007). Evaluating corn silage quality for dairy cattle. Retrieved from fyi.extension.wisc.edu/forage/ evaluating-corn-silage-quality-for-dairy-cattle/

Shaver, R., Hoffman, P., Lauer, J., \& Coors, J. (n.d.). Milk2006. University of Wisconsin corn silage evaluation system. Retrieved from corn.agronomy.wisc.edu/season/DSS/Milk2006CornSilage_v313.xls

Sheaffer, C., Halgerson, J., \& Jung, H. (2006). Hybrid and N fertilization affect corn silage yield and quality. Journal of Agronomy and Crop Science, 283, 278-283. https://doi.org/10.1111/j.1439-037X. 2006.00210.x

Shenk, J. S., \& Westerhaus, M. O. (1991). Population structuring of near infrared spectra and modified partial least squares regression. Crop Science, 31, 1548-1555. https://doi.org/10.2135/cropsci1991. 0011183X003100060034x

Sierra, J. (1992). Relationship between mineral N content and N mineralization rate in disturbed and undisturbed soil samples incubated under field and laboratory conditions. Australian Journal of Soil Research, 30, 477-492. https://doi.org/10.1071/SR9920477
USDA Economic Research Service (USDA-ERS). (2019). Fertilizer use and price. Retrieved from https://www.ers.usda.gov/data-products/ fertilizer-use-and-price.aspx

USDA National Agricultural Statistics Service (USDA-NASS). (2020). Quick stats. Retrieved from https://quickstats.nass.usda.gov/results/ 3B9FD750-0650-34A7-AE8A-279A87C3D240

Van Deynze, A., Putnam, D., Orloff, S., Lanini, T., Canevari, M., Vargas, R., ... Teuber, L. (2004). Roundup Ready alfalfa: An emerging technology. Davis: University of California Division of Agriculture and Natural Resources.

Van Roekel, R. J., \& Coulter, J. A. (2011). Agronomic responses of corn to planting date and plant density. Agronomy Journal, 103(5), 1414. https://doi.org/10.2134/agronj2011.0071

Winfield. (2020). 2,4-D LV6 herbicide label. Retrieved from http://www. cdms.net/ldat/ld971000.pdf

Wu, T.-Y., Ma, B. L., \& Liang, B. C. (2008). Quantification of seasonal soil nitrogen mineralization for corn production in eastern Canada. Nutrient Cycling in Agroecosystems, 81, 279-290. https://doi.org/10. 1007/s10705-007-9163-x

Yost, M. A., Coulter, J. A., \& Russelle, M. P. (2013). First-year corn after alfalfa showed no response to fertilizer nitrogen under notillage. Agronomy Journal, 105, 208-214. https://doi.org/10.2134/ agronj2012.0334

Yost, M. A., Coulter, J. A., Russelle, M. P., Sheaffer, C. C., \& Kaiser, D. E. (2012). Alfalfa nitrogen credit to first-year corn: Potassium, regrowth, and tillage timing effects. Agronomy Journal, 104, 953962. https://doi.org/10.2134/agronj2011.0384

Yost, M. A., Russelle, M. P., \& Coulter, J. A. (2013). Nitrogen requirements of first-year corn following alfalfa were not altered by fallapplied manure. Agronomy Journal, 105, 1061-1069. https://doi.org/ 10.2134/agronj2012.0496

Yost, M. A., Russelle, M. P., \& Coulter, J. A. (2014). Field-specific fertilizer nitrogen requirements for first-year corn following alfalfa. Agronomy Journal, 106, 645-658. https://doi.org/10.2134/agronj2013. 0416

\section{SUPPORTING IN FORMATION}

Additional supporting information may be found online in the Supporting Information section at the end of the article.

How to cite this article: Clark JD, Yost MA, Griggs

$\mathrm{TC}$ et al. Nitrogen fertilization and glyphosate-resistant alfalfa termination method effects on first-year silage corn. Agronomy Journal. 2021;113:1-12. https://doi.org/10.1002/agj2.20583 